\title{
Promoting the use of home-mixed supplements as alternatives to commercial supplements in smallholder beef production systems in the subhumid region of Zimbabwe
}

\author{
Irenie Chakoma1, Godfrey Manyawuํ, Lovemore C Gwiriri, Siboniso Moyo², Sikhalazo Dube ${ }^{1}$, Venancio E Imbayarwo- \\ Chikosi $^{3}$, Tinyiko E Halimani ${ }^{3}$, Charles Chakoma ${ }^{4}$, Barbara V Maasdorp ${ }^{5}$ and Victor Buwu ${ }^{3}$ \\ ${ }^{1}$ International Livestock Research Institute, c/o CIMMYT Southern Africa Regional Office, Harare, Zimbabwe \\ 2 International Livestock Research Institute, Addis Ababa, Ethiopia \\ ${ }^{3}$ Department of Animal Science, University of Zimbabwe, Harare, Zimbabwe \\ 4 Independent, Harare, Zimbabwe \\ ${ }^{5}$ Department of Crop Science, University of Zimbabwe, Harare, Zimbabwe \\ *Corresponding author, email: i.chakoma@cgiar.org
}

\begin{abstract}
The economic and performance effect of supplementing smallholder cattle by substituting commercial feed with iso-nitrogenous and iso-energetic diets based on alternative protein sources was investigated in two trials. In trial 1, three diets (commercial concentrate, commercial concentrate partially substituted with mucuna, and commercial concentrate partially substituted with lablab-cowpea) compared with veld grass were allocated to 12 cattle in a complete randomised block design. In trial 2, a double complete randomised block design with 40 cattle assigned to four forage legume-based diets, a poultry-based diet and a commercial beef concentrate was carried out. Diets were offered at $1.5 \%$ of body weight daily over $56 \mathrm{~d}$. Average daily weight gain (ADWG) was measured weekly in trial 1 and fortnightly in trial 2 . In trial 1, ADWG was significantly $(p<0.05)$ higher for animals on supplements compared with non-supplemented cattle. In trial 2, ADWG was significantly highest on the groundnut stover-based diet and least on the poultry litter diet. Supplementation had a positive effect on ADWG and economic performance of smallholder beef cattle. Substitution of commercial concentrates with alternative protein sources reduced diet costs and significantly improved gross margins.
\end{abstract}

Keywords: average daily weight gain, beef cattle, feed alternatives, gross margin, Zimbabwe

\section{Introduction}

Approximately $70 \%$ of the world's rural households derive their livelihoods from agriculture through integrated crop and livestock subsistence farming (World Bank 2008; FAO 2009). In developing countries, cattle play an integral role in the livelihoods of communal smallholder farmers by providing economic, social and food security roles. According to the Second Round Crop and Livestock Forecasting Report (MoAMID 2014) for Zimbabwe, $90 \%$ of cattle are owned by smallholder farmers $(68 \%$ communal, $11 \%$ new resettlement, $7 \%$ old resettlement, $4 \%$ small-scale commercial farming) and $10 \%$ are owned by the large-scale commercial farming sector. However, the contribution of livestock to rural livelihoods and household economic food security remains limited owing to various challenges.

Key to smallholder livestock production, which is predominantly extensive and communally based, is rangeland quality and quantity. Inadequate nutritional value of rangeland fodder, particularly during the dry season, reduces rangeland capacity to meet the recommended livestock nutritional requirements, resulting in reduced animal performance. Crude protein content of veld declines from as much as $15 \%$ in summer to as low as $3 \%$ during the dry season (Topps and Oliver 1993). Farmers need to supplement their cattle during this period.

However, smallholder farmers rarely provide supplementary feed to their beef cattle during the dry season due to the high cost of commercial supplements, resulting in decline in productivity (Matibvu et al. 2012; Tavirimirwa et al. 2012). Therefore, livestock sold during this period has low market value due to their poor condition. This period also coincides with the lean period in household food security in Zimbabwe, hence livestock is sold to cover household food and related needs. It follows that the contribution of cattle to economic household food security in the dry season is limited.

Studies have indicated the potential of smallholder livestock to fetch better prices and contribute significantly to economic household food security through supplementation. Studies by Prasad et al. (1994) and Israel and Pearson (2000) suggest that supplementing cattle feed, especially during the dry season, improves animal performance, particularly oxen. However, the cost of commercial supplementary feeds is prohibitive for smallholder farmers to supplement their cattle. Most smallholder farmers supplement veld grazing with untreated maize stover, which has low nutritive value, thus limiting performance. 
Research has indicated the viability of using alternative locally available feed resources. Groundnut stover has been noted to be a good source of protein (Etela and Dung 2011). Groundnut, being one of the major crops grown by smallholder farmers in Zimbabwe, produces a substantial amount of stover. However, the stover is discarded mostly in smallholder farming systems. Etela and Dung (2011) suggest using groundnut stover as cattle feed, especially during the dry season. Poultry litter has also been suggested as a viable protein source for smallholder cattle, though processing before feeding may be required to control pathogenic micro-organisms (Fontenot and Hancock 2001; Mhaka 2014). A significant number of smallholder farmers in Zimbabwe rear backyard chickens (broilers and layers) for sale and home consumption. Therefore, there is production of significant quantities of poultry litter, which can be used as a cheap source of protein. Utilisation and adoption of these alternative protein sources in smallholder systems has often been limited by lack of (1) information on inclusion levels in cattle rations and (2) demonstration of their feeding value being translated to income from cattle sales.

Further to the above alternative protein sources, forage legumes have been recognised as alternative cheap sources of feed (Murphy and Colucci 1999), as they are adaptable and produce reasonable quantities of biomass. Research has highlighted the potential of forage legumes in alleviating the dry-season feed shortages. This is despite the fact that forage legumes are known to contain anti-nutritional factors that reduce their utilisability (Matenga et al. 2003). Studies have indicated that supplementation with forage legumes results in weight gain in cattle and goats (Buwu 2014; Gusha et al. 2015a). Irrespective of ample research showing forage legume potential as a livestock feed resource, adoption rates are relatively low in smallholder farming systems (Mapiye et al. 2006). As with groundnut stover and poultry litter, demonstration of the economic feasibility of utilising forage legumes in smallholder systems is lacking. It also follows that lack of demonstration on how supplementation can contribute to improved household income from cattle affects adoption rates. Most smallholder farmers adopt technologies that have been demonstrated to translate into income.

The objectives of this study were to (1) demonstrate the economic and performance effect of supplementing smallholder beef cattle by partially substituting commercial supplements with forage legumes and (2) evaluate the performance of smallholder beef cattle fed forage legumes, groundnut stover and poultry litter as alternative protein sources for livestock feeding with the objective of selling the livestock.

\section{Materials and methods}

\section{Study sites}

The trials were conducted in Goromonzi $\left(17^{\circ} 29^{\prime} \mathrm{S}\right.$,

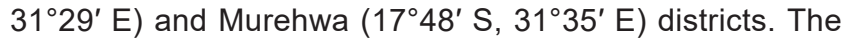
areas are located in agro-ecological region Ilb and have comparatively similar climatic conditions. Annual rainfall of about $750-900 \mathrm{~mm}$ is received between October/November and March/April each year with the remaining seven to eight months being dry. Temperatures average a maximum of $25^{\circ} \mathrm{C}$ and a minimum of $10{ }^{\circ} \mathrm{C}$. The main agricultural activities in these districts are crop (maize, groundnuts and cowpea) and livestock (cattle, goats and poultry) production.

\section{Diets}

Trial 1 consisted of three iso-nitrogenous and iso-energetic diets (commercial concentrate; commercial concentrate partially substituted with mucuna; and commercial concentrate partially substituted with lablab-cowpea) being compared with veld grazing. Iso-nitrogenous and iso-energetic diets are diets that have the same amount of dietary nitrogen and energy, respectively. The diets are as indicated in Table 1. Trial 2 consisted of five iso-nitrogenous and iso-energetic diets. The diets composition is as indicated in Table 1.

Lablab and mucuna hay were harvested at the early flowering stage, dried for 2-3 d and then baled. Forage seed was harvested dry and included in the diet as crushed bean. Groundnut stover was made from the vegetative groundnut tops after harvesting the pods, consisting of the dry leaf and stem material. Poultry litter (consisting of wheat straw and broiler chicken droppings) was collected and sun-dried for an average of $3 \mathrm{~d}$ until completely dry. Commercial concentrate (32\% crude protein [CP]) was purchased. Hays, stover and poultry litter were milled using a chopper grinder to approximately $3 \mathrm{~cm}$ length before being mixed in the respective diets.

The methods of the Association of Official Analytical Chemists (AOAC 1990) were used to determine the dry matter of the composite samples of the feeds. Crude protein was determined by the standard Kjeldahl procedure (AOAC 1990), and the bomb calorimetric method (AOAC 1995) was used to determine energy content.

\section{Animal management}

The trial was conducted over two years. Trial 1 in the 2013 dry season was conducted in Goromonzi district only, and trial 2 in the 2014 dry season was conducted in Goromonzi and Murehwa districts. In trial 1, 12 Mashona crossbred cattle (six male castrates and six multiparous females) were fed three diets over a 56-day feeding period. In trial 2, 40 Mashona crossbred cattle (20 male castrates and 20 multiparous females) were fed five diets over the same period. However, during the progression of trial 2 , one animal was disposed of at day 44 , hence only 39 animals were fed for the complete period of $56 \mathrm{~d}$. The animals were aged $3( \pm 1)$ years in both trials. The animals were fed for a seven-day adaptation period before data collection commenced. Animals were offered diets at $1.5 \%$ of bodyweight in the morning and afternoon by dividing the daily allowance into two equal portions. Clean water and basal untreated maize stover were offered ad libitum.

At the start of the trials, all cattle were drenched with Benvet $^{\circledR}$, a broad-spectrum anthelmintic for the treatment and control of liver flukes and gastrointestinal parasites. A vitamin injection was also administered before the onset of the supplementation to boost appetite. The cattle were housed in free-stall pens at the respective farm sites and each animal allocated an individual feeding trough. 
Table 1: Nutritional composition (\%) and costs of diets fed to beef animals in Goromonzi and Murehwa districts, Zimbabwe

\begin{tabular}{|c|c|c|c|c|c|c|c|c|c|c|c|c|c|c|c|c|c|c|}
\hline \multirow{3}{*}{ Ingredient } & \multicolumn{8}{|c|}{ Treatments for trial $1^{1}$} & \multicolumn{10}{|c|}{ Treatments for trial $2^{1}$} \\
\hline & \multicolumn{2}{|c|}{ M1 } & \multicolumn{2}{|c|}{ LC1 } & \multicolumn{2}{|c|}{$\mathrm{C} 1$} & \multicolumn{2}{|c|}{ VG1 } & \multicolumn{2}{|c|}{ M2 } & \multicolumn{2}{|c|}{ L2 } & \multicolumn{2}{|c|}{ GS2 } & \multicolumn{2}{|c|}{ PL2 } & \multicolumn{2}{|c|}{$\mathrm{C} 2$} \\
\hline & $(\%)$ & $\begin{array}{l}\text { Cost } \\
\text { (US\$) }\end{array}$ & $(\%)$ & $\begin{array}{c}\text { Cost } \\
\text { (US\$) }\end{array}$ & $(\%)$ & $\begin{array}{l}\text { Cost } \\
\text { (US\$) }\end{array}$ & $(\%)$ & $\begin{array}{c}\text { Cost } \\
\text { (US\$) }\end{array}$ & $(\%)$ & $\begin{array}{l}\text { Cost } \\
\text { (US\$) }\end{array}$ & $(\%)$ & $\begin{array}{l}\text { Cost } \\
\text { (US\$) }\end{array}$ & $(\%)$ & $\begin{array}{l}\text { Cost } \\
\text { (US\$) }\end{array}$ & $(\%)$ & $\begin{array}{l}\text { Cost } \\
\text { (US\$) }\end{array}$ & $(\%)$ & $\begin{array}{c}\text { Cost } \\
\text { (US\$) }\end{array}$ \\
\hline Maize & 41 & 0.11 & 45 & 0.12 & 43 & 0.11 & - & - & 40 & 0.14 & 40 & 0.14 & 40 & 0.14 & 40 & 0.14 & 79 & 0.29 \\
\hline Mucuna hay & 25 & 0.06 & - & - & - & - & - & - & 35 & 0.05 & - & - & - & - & - & - & - & - \\
\hline Mucuna bean & 10 & 0.05 & - & - & - & - & - & - & 24 & 0.09 & - & - & - & - & - & - & - & - \\
\hline Lablab hay & - & - & 16 & 0.03 & - & - & - & - & - & - & 45 & 0.08 & - & - & - & - & - & - \\
\hline Cowpea shells & - & - & 17 & 0.03 & - & - & - & - & - & - & - & - & - & - & - & - & - & - \\
\hline Soya meal & - & - & - & - & - & - & - & - & - & - & 14 & 0.01 & 16 & 0.01 & - & - & - & - \\
\hline Soya hay & 10 & 0.01 & 4 & 0.02 & 36 & 0.05 & - & - & - & - & - & - & - & - & - & - & - & - \\
\hline Beef concentrate & 13 & 0.04 & 17 & 0.05 & 20 & 0.07 & - & - & - & - & - & - & - & - & - & - & 20 & 0.07 \\
\hline Groundnut stover & - & - & - & - & - & - & - & - & - & - & - & - & 43 & 0.06 & - & - & - & - \\
\hline Poultry litter & - & - & - & - & - & - & - & - & - & - & - & - & - & - & 45 & 0.03 & - & - \\
\hline Maize stover & - & - & - & - & - & - & - & - & - & - & - & - & - & - & 14 & 0.01 & - & - \\
\hline Vitamin + mineral mix & 1 & 0.02 & 1 & 0.02 & 1 & 0.03 & - & - & 1 & 0.01 & 1 & 0.01 & 1 & 0.01 & 1 & 0.01 & 1 & 0.01 \\
\hline Dry matter (\%) & \multicolumn{2}{|c|}{89.7} & \multicolumn{2}{|c|}{89.2} & \multicolumn{2}{|c|}{89.3} & \multicolumn{2}{|c|}{91.7} & \multicolumn{2}{|c|}{89.9} & \multicolumn{2}{|c|}{89.4} & \multicolumn{2}{|c|}{90.5} & \multicolumn{2}{|c|}{91.2} & \multicolumn{2}{|c|}{89.3} \\
\hline Crude protein (\%) & \multicolumn{2}{|c|}{13.9} & \multicolumn{2}{|c|}{13.7} & \multicolumn{2}{|c|}{14.2} & \multicolumn{2}{|c|}{5.70} & \multicolumn{2}{|c|}{13.8} & \multicolumn{2}{|c|}{14.1} & \multicolumn{2}{|c|}{13.9} & \multicolumn{2}{|c|}{14} & \multicolumn{2}{|c|}{14.2} \\
\hline Energy (MJ kg-1 DM) & & 1.5 & & 1.6 & & 1.4 & & .90 & & 1.7 & & 1.5 & & 1.5 & & 1.6 & & 1.4 \\
\hline Feed cost (US\$ kg-1) & & 29 & & 27 & & 26 & & - & & 27 & & 33 & & 31 & & 19 & & 37 \\
\hline
\end{tabular}

1 Treatment diets: M1 = mucuna, LC1 = lablab-cowpea, C1 = beef concentrate, VG1 = veld grazing, M2 = mucuna, L2 = lablab, GS2 = groundnut stover, PL2 = poultry litter, C2 = beef

\section{Data collection}

In trials 1 and 2, data on weight gain, body condition score, feed intake and refusals was recorded every $7 \mathrm{~d}$ and fortnightly, respectively. Body condition score was measured on a scale of 1-5 (1 = poor condition and 5 excellent condition) in both trials.

Data collection was over a 56-day period in both trials. Smallholder farmers normally feed for less than $60 \mathrm{~d}$ due to feed availability and cost (Mlote et al. 2013). Feeding period depends on feed availability and coincidence with marketing time for the animals as determined by prevailing market prices (Holness 1998).

\section{Trial design}

In trial 1, a randomised complete block design was used. Twelve cattle were ranked using initial live weight and divided into three weight groups of four animals $(<200 \mathrm{~kg}$, $201-320 \mathrm{~kg}$ and $>320 \mathrm{~kg}$ ). Within each group, the animals were randomly allocated to the four treatments. Offered treatment quantities were adjusted after every $7 \mathrm{~d}$ according to the previous weight measurement.

In trial 2, a double randomised block design was used with 20 animals in Goromonzi district and replicated with 20 animals in Murehwa district. In each of the two districts, the 20 animals were divided into four weight groups of five animals ( $<200 \mathrm{~kg}, 201-300 \mathrm{~kg}, 301-400 \mathrm{~kg}$ and $>400 \mathrm{~kg}$ ). Within each group, the animals were randomly allocated to the five treatments. Offered treatment quantities were adjusted fortnightly according to the previous weight measurement.

\section{Statistical analysis}

Data were subjected to analysis of variance using the Mixed Procedure for repeated measures of SAS 12.1 (SAS Institute 2012) with the initial live weight being used as a covariate. Comparison of treatment means was done using the Tukey post-hoc test.

The model used for the analysis was as follows:

$$
Y_{i j k l}=\mu+\beta I_{i}+T_{j}+S_{k}+W_{1}+e_{i j k l}
$$

where $Y_{i j k l}$ is bodyweight, $\mu$ is the overall mean common to all observations, $\beta$ is the linear regression coefficient of initial weight on the response variable, $I_{i}$ is the initial body weight (covariate), $T_{j}$ is the fixed effect of treatment $(j=1,2$, $3,4,5), S_{k}$ is the fixed effect of $\operatorname{sex}(k=1,2), W_{l}$ is the fixed effect of time $(I=1,2,3,4)$ and $e_{i j k l}$ is the normally distributed random error.

One of the animals was sold during the trial, therefore the analysis was adjusted accordingly.

\section{Gross margin analysis}

The gross margin of the beef cattle feeding trial was determined by calculating the difference between total income and total variable costs. Total income per treatment was calculated as the summation of the optimum selling price for each animal. This was calculated as an average of the value of animals slaughtered at the abattoir, animals sold on the hoof and those valued at the end of the feeding period. Total variable costs were calculated as a summation of initial live weight price of the animal, feed costs, veterinary costs, labour, transport, slaughter fee, and regulatory costs, such as Rural District Council levy and cattle movement permit issued by the Department of Veterinary Services in association with the Zimbabwe Republic Police.

$$
\mathrm{GM}_{x}=\sum_{i=1}^{n} \mathrm{TI}_{i}-\sum_{i=1}^{n} \mathrm{TVC}_{i}
$$

where $\mathrm{GM}_{x}$ is gross margin ( $x=$ treatment diet), $\sum_{i=1}^{n} \mathrm{Tl}_{i}$ is summation of the total income ( $\mathrm{TI})$ for each animal 
$(i=1,2, \ldots)$ and $\sum_{i=1}^{n} \mathrm{TVC}_{i}$ is summation of the total variable costs (TVC) for each animal $(i=1,2, \ldots)$.

\section{Results}

\section{Animal performance}

No significant differences in intake were recorded. Animals consumed and finished the allocated $1.5 \%$ of body weight ration. Therefore, there were no refusals observed and recorded in both trials. Supplemented animals had improved body condition compared to animals grazing on veld, from an average body condition score of 2.6 to 3.2. On the other hand, body condition of unsupplemented animals deteriorated from an average of 2.6 to 2.0.

In trial 1, there were no significant differences in average daily weight gain (ADWG) among cattle offered supplementary feed, but ADWG was, however, significantly higher than those grazing on veld. The ADWG of cattle offered supplementary feed (mucuna based diet: $1.04 \mathrm{~kg}$ head ${ }^{-1} \mathrm{~d}^{-1}$; lablab-cowpea based diet: $0.88 \mathrm{~kg}$ head ${ }^{-1} \mathrm{~d}^{-1}$; and commercial concentrate based diet: $0.69 \mathrm{~kg}$ head $\left.\mathrm{d}^{-1} \mathrm{~d}^{-1}\right)$ was significantly higher $(p<0.05)$ than that of cattle grazing on veld $\left(0.28 \mathrm{~kg}\right.$ head $\left.^{-1} \mathrm{~d}^{-1}\right)$. For the entire feeding period, while the mean live weight gains for animals offered mucuna substituted diet $(60.3 \mathrm{~kg})$ and lablabcowpea substituted diet $(55.0 \mathrm{~kg})$ were not significantly different from each other $(p>0.05)$, they were significantly higher $(p<0.05)$ than those for cattle offered commercial concentrate based diet $(34.5 \mathrm{~kg})$ and veld grazing $(16.1 \mathrm{~kg})$. The seven-day weight gains increased gradually in the first $28 \mathrm{~d}$, reaching a peak at $35 \mathrm{~d}$ and levelling off from $42 \mathrm{~d}$ until the end of the trial (Figure 1).

In trial 2, there were significant differences in ADWG of cattle offered supplementary feeding. Mean live weight gain over the feeding period was significantly higher $(p<0.05)$

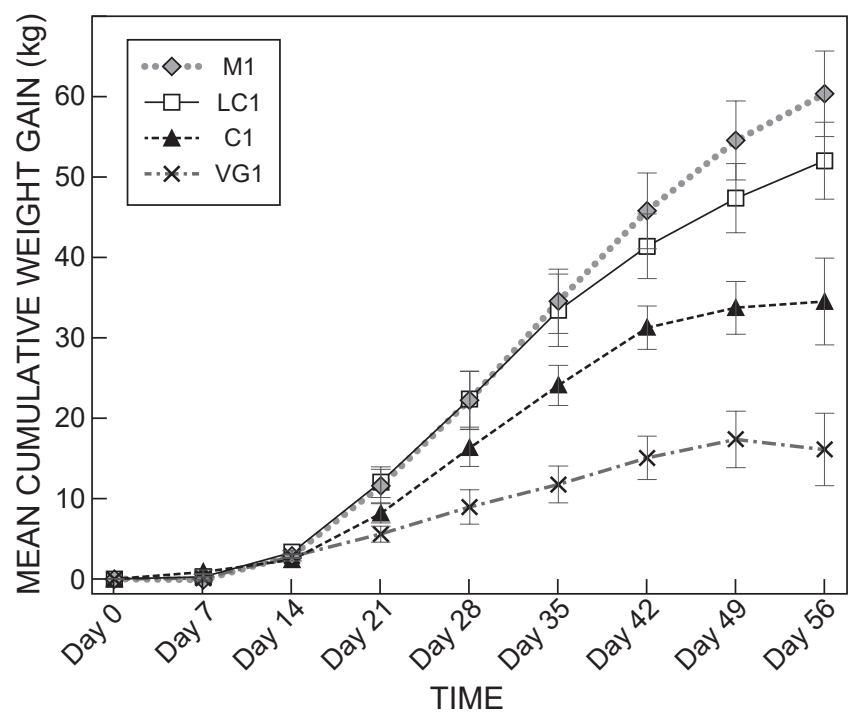

Figure 1: Mean cumulative weight gain of cattle offered different dietary treatments in trial 1 in Goromonzi district, Zimbabwe $(n=3)$. M1 = mucuna based diet, LC1 = lablab-cowpea based diet, C1 = beef concentrate based diet, VG1 = veld grazing for cattle offered groundnut stover diet $(42.7 \mathrm{~kg})$, whereas animals offered poultry litter based diet had the least mean live weight gain $(28.0 \mathrm{~kg})$ (Figure 2). There were significant differences $(p<0.05)$ in ADWG between the weighing periods (14 d), especially for the first and second weighing periods (Figure 2). Animals grazing on veld lost weight after day 49 .

\section{Economic analysis \\ Dietary costs}

In trial 1 , the dietary cost for the mucuna-based substituted ration and the lablab-cowpea substituted ration were higher compared with that of the commercial concentrate. However, in trial 2 dietary cost for the forage legume based diets was lower than for the commercial concentrate (Table 1). Table 1 indicates that the cost of commercial concentrate in trial 1 (US\$0.26 kg-1) was lower than in trial 2 (US\$0.37 $\mathrm{kg}^{-1}$ ). Table 1 also shows that the cost of the lablab-cowpea substituted diet used in trial 1 was lower than that of the lablab-only diet used in trial 2.

\section{Gross margin analysis}

In trial 1, labour costs for the control group (VG1) was higher as they included herding the animals (Table 2). Transport cost was higher for the commercial based diet than the rest of the diets (the cost calculated included the transport cost to ferry feed from the market). The mucunabased substituted diet had the highest return per head and veld grazing the least.

In trial 1, it can be noted that income from supplemented cattle was higher than that of non-supplemented animals.

In trial 2 (Table 3 ) gross margin per animal was highest on the mucuna based diet (US\$122), whereas those animals on poultry litter had the least gross margin (US\$51.4). The gross margin from cattle offered poultry

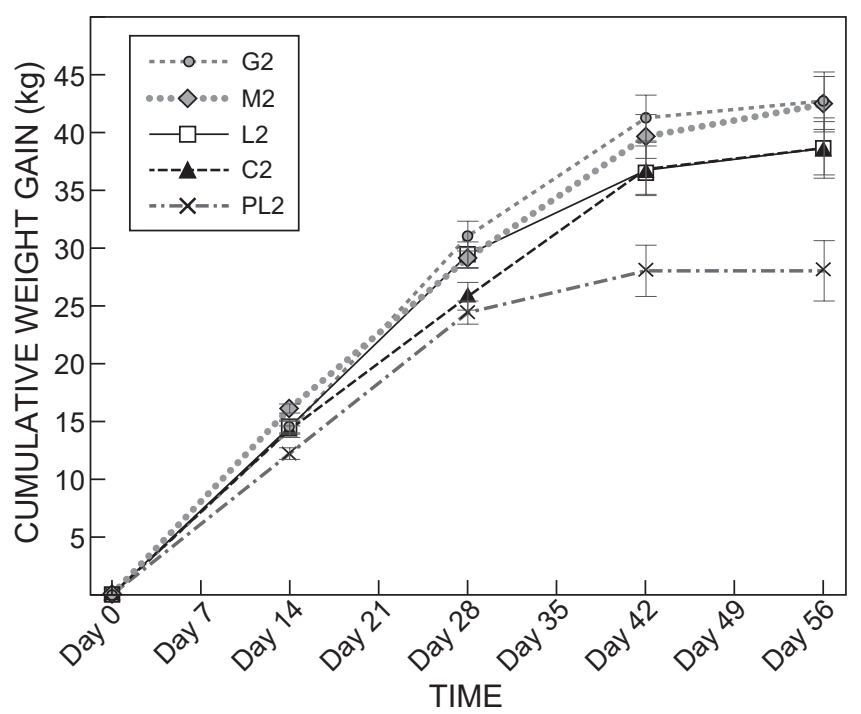

Figure 2: Mean cumulative weight gain of 39 cattle offered different dietary treatments in trial 2 in Goromonzi and Murehwa districts, Zimbabwe $(n=8)$. G2 = groundnut stover, M2 = mucuna, L2 = lablab, C2 = beef, PL2 = poultry litter 
litter was less than $50 \%$ of the gross margin obtained from cattle offered the other treatment diets.

\section{Discussion}

\section{Animal performance}

No refusals were recorded in trials 1 and 2, indicative of no significant differences in intake. Animals were offered supplement at $1.5 \%$ of body weight, in two equal portions daily, which they finished with no observed refusals. According to Madzimure et al. (2011), intake is determined by CP level, form and anti-nutritional factors. The diets contained approximately $14 \% \mathrm{CP}$, which was higher than $7 \% \mathrm{CP}$, below which it has been documented to affect intake negatively (Milford and Minson 1966). The forages were fed in a dried form, and Madzimure et al. (2011) further assert that dried forages do not affect intake negatively.

Body condition score of the supplemented animals improved and were comparable to those on commercial diet. Supplementation has been noted to improve performance and body condition of the animals. Israel and Pearson (2000) concur that supplementation improves body condition and animal performance significantly.
In trial 1, there were no significant differences in ADWG between animals on the forage legume substituted diets and commercial concentrate, but ADWG was significantly higher than on animals grazing on veld. However, cattle on mucuna-based substituted diet had the highest total weight gain than animals on the other diets. Similar results were observed by other authors where improved performance of cattle fed mucuna was observed (Muinga et al. 2003; Murungweni et al. 2004). In a study by Gwanzura et al. (2011), it was observed that goats fed mucuna had the highest intake and weight gain compared with those on lablab and cowpea treatments. Mucuna has been noted to be an excellent source of fermentable nitrogen and energy, and has an amino acid and mineral profile similar to soya bean (Ayala-Burgos et al. 2003). This could explain the performance in cattle offered the mucuna-based substituted diet. Animals that did not receive any supplementation (animals grazing on veld only) had the least weight gain, with animals losing weight after day 49 . Veld condition deteriorates during the drier months, with related poor quantity and quality of grazing, hence reduced performance in animals on veld grass only during the drier months has often been reported. Cattle in the tropics mainly depend

Table 2: Gross margin analysis for treatments in trial 1

\begin{tabular}{lcccc}
\hline \multirow{2}{*}{ Income and expenditure } & \multicolumn{4}{c}{ Treatment $^{1}$} \\
\cline { 2 - 5 } & M1 & LC1 & C1 & VG1 \\
\hline Total income (US\$) & 1660 & 1600 & 1590 & 1320 \\
\hline Expenditure (US\$) & & & & \\
$\quad$ Initial livestock costs & 878 & 872 & 809 & 888 \\
Feed costs & 192 & 178 & 183 & 3.72 \\
Other expenses: Labour costs & 40.0 & 40.0 & 40.0 & 60.0 \\
$\quad$ Veterinary costs & 6.00 & 6.06 & 6.72 & 7.36 \\
Transport costs & 25.0 & 25.0 & 37.5 & 25.0 \\
Slaughter fee & 50.0 & 50.0 & 50.0 & 50.0 \\
Regulatory expenses & 12.0 & 12.0 & 12.0 & 12.0 \\
Total costs & 1200 & 1180 & 1140 & 1050 \\
\hline Gross margin (US\$) & 460 & 421 & 448 & 277 \\
Gross margin (US\$ animal ${ }^{-1}$ ) & 153 & 140 & 149 & 92 \\
\hline
\end{tabular}

1 Treatments: M1 = mucuna based diet, LC1 = Lablab-cowpea based diet, C1 = commercial based diet, VG1 = veld grazing

Table 3: Gross margin analysis for treatment diets/animal for trial 2

\begin{tabular}{lccccc}
\hline \multirow{2}{*}{ Income and expenditure } & \multicolumn{5}{c}{ Treatment $^{1}$} \\
\cline { 2 - 5 } & M2 & L2 & GS2 & PL2 & C2 \\
\hline Income (US\$) & 652 & 654 & 628 & 442 & 657 \\
\hline Expenditure (US\$) & 343 & 342 & 325 & 256 & 325 \\
$\quad$ Initial livestock cost & 75.3 & 89.2 & 74.1 & 23.3 & 101 \\
Feed costs & 40.0 & 40.0 & 40.0 & 40.0 & 40.0 \\
Other expenses: Labour costs & 4.00 & 4.00 & 4.00 & 4.00 & 4.00 \\
$\quad$ Veterinary costs & 25.0 & 25.0 & 25.0 & 25.0 & 30.0 \\
Transport & 25.0 & 25.0 & 25.0 & 25.0 & 25.0 \\
Slaughter fee & 17.5 & 17.5 & 17.5 & 17.5 & 17.5 \\
Regulatory expenses & 530 & 543 & 511 & 391 & 543 \\
Total costs & 122 & 110 & 117 & 51 & 114 \\
\hline Gross margin (US\$ animal & -1 ) & 12.0 &
\end{tabular}

1 Treatments: M2 = mucuna based diet, L2 = lablab based diet, GS2 = groundnut stover based diet, PL2 = poultry litter based diet, $\mathrm{C} 2$ = commercial based diet 
on feed resources that are low in $\mathrm{CP}$ especially in the dry season and addition of protein-rich feed sources would be beneficial (Wanapat 2000). The low weight gains in the animals on veld grazing could have been a result of limited intake coupled with low dry matter digestibility associated with the poor quality of veld forage in the drier months. Digestibility and utilisation of veld grazing material is negatively affected by the low CP content.

In trial 2, animals on groundnut stover had the highest ADWG. Packard et al. (2007) achieved significantly higher ADWG with goats when fed groundnut stover. The authors concluded that supplementing goats with groundnut stover may improve ADWG when browse is scarce or of poor quality. Studies have indicated that groundnut based feeds have high digestibility (Adamu 2015), which could explain why animals offered groundnut stover based diet performed better than those on the other diets. Francis and Ndlovu (1995) also reported better oxen performance when supplemented with cob sheath groundnut stover. Chakeredza et al. (2002) reported no difference in digestibility when weaner lambs were fed cowpea and groundnut based diets. However, the authors reported higher metabolisable energy intake with cowpea based diet than that of groundnut based diet.

Poultry litter had the least ADWG. Poultry litter has been found to be safe for inclusion in supplementary diets for ruminants (El-Sabban et al. 1970; Tadele and Amha 2015). However, poultry litter quality is variable and is affected by the type and quality of straw used, quality of the feed fed to the poultry and processing method, which invariably affects digestibility. This could explain the lower ADWG recorded in trial 2.

The mean live weight gain increased gradually in the first four weeks, reaching a peak in week five and levelling off from week six until the end of the trials (Figures 1 and 2). This finding concurs with the normal growth curve exhibited by animals.

\section{Economic analysis}

In Zimbabwe the unit price of beef depends on grade and weight. Profitability of supplementary feeding is a function of the selling price, input costs and performance factors, such as live weight gain and change in carcass parameters. Animals in the trial improved weight and body condition score, which contributes to the grade. This could explain the higher prices fetched from supplemented cattle.

Most studies have indicated that supplementing with residues, forage legumes or stover reduces the dietary cost. However, in trial 1 where commercial concentrate was substituted by forage legume, the diets were more expensive. This was due to scarcity of the forage seed and resultant hay. In the first year of the trial, forage legume seed was unavailable in the Zimbabwean seed market, hence seed was imported at US\$9.00 $\mathrm{kg}^{-1}$, which drove the production cost for hay and seed prices up at the end of the 2013 growing season. However, in the second year, after seed bulking and redistribution, demand for the seed had dampened, which reduced the price, as evident in the cheaper diets in trial 2.

Feed is one of the major cost drivers in beef cattle feeding and marketing. Feeding of forage legumes as protein sources is expected to lower variable costs (Gusha et al. 2015a). Gross margins were higher for animals supplemented with forage legume based diets, specifically mucuna based diets in both trials. This was a result of the related lower feed costs and improved animal performance. The results indicate that smallholder farmers can improve economic returns and gross margin by supplementing with low-cost protein alternatives. Partial or complete substitution of feed ingredients with forages or poultry litter as protein sources enabled farmers to source feed locally, utilise what is available at the farm, whilst getting more or less the same animal perfomance as with commercial feed. Several studies have also concluded with recommending use of alternative protein sources to reduce feed and associated costs, thereby increasing overall profitability (Jokthan et al. 2013; Mhaka 2014; Gusha et al. 2015b). Fluctuations in the pricing of beef in Zimbabwe generally follow seasonal availability of beef quality and quantity. It therefore follows that the price margins for beef are generally high during the dry season when beef of higher grade and quality is in short supply as a result of a decline in feed quality and general lack of supplementary feeding by smallholder farmers.

\section{Conclusion}

Supplementing cattle using alternative protein sources, especially in the dry season, has the potential to improve livestock production in the smallholder sector. Supplemented cattle have improved gross margins, increasing the contribution of livestock to household income. While partial substitution of commercial diets with forage-based diets has been demonstrated to reduce feed costs, complete forage-based rations significantly reduce feed costs further. Cattle supplemented with forage-based rations have improved average daily weight gain during the dry season. Smallholder farmers who bridge the dry-season feed shortage gap using on-farm forage-based rations have the potential to improve income from beef due to seasonally higher beef prices, contributing to livelihood resilience.

\section{References}

Adamu YH. 2015. Assessment of two groundnut (Arachis hypogaea L) varieties for forage, pod yield characteristics and effect of feeding the haulm to Yankasa rams. PhD thesis, Ahmadu Bello University, Nigeria.

AOAC (Association of Official Analytical Chemists). 1990. Official methods of analysis (15th edn). Washington, DC: AOAC.

AOAC. 1995. Official methods of analysis (16th edn). Arlington, VA: AOAC.

Ayala-Burgos AJ, Herrera-DíazPE, Castillo-Caamal JB, RosadoRivas CM, Osornio-Muñoz L, Castillo-Caamal AM. 2003. Rumen degradability and chemical composition of velvet bean (Mucuna spp.) grain and husk. Tropical and Subtropical Agroecosystems 1: 71-75.

Buwu V. 2014. Intensification of smallholder beef production systems using tropical forage legumes. MSc thesis, University of Zimbabwe, Zimbabwe.

Chakeredza S, ter Meulen U, Ndlovu LR. 2002. Effect of cowpea hay, groundnut hay, cotton seed meal and maize meal supplementation to maize stove on intake, digestibility, microbial protein supply and acetate kinetics in weaner lambs. Tropical 
Animal Health and Production 34: 49-64.

El-Sabban FF, Bratzler JW, Long TA, Frear DEH, Gentry RF. 1970. Value of processed poultry waste as a feed for ruminants. Journal of Animal Science 31: 107-111.

Etela I, Dung DD. 2011. Utilization of stover from six improved dual-purpose groundnut (Arachis hypogaea L.) cultivars by West African dwarf sheep. African Journal of Food, Agriculture, Nutrition and Development 11: 4538-4545.

FAO (Food and Agriculture Organization of the United Nations). 2009. The state of food and agriculture: livestock in the balance. Rome: FAO.

Fontenot JP, Hancock JW. 2001. Utilisation of poultry litter as feed for beef cattle. Paper presented at FDA public hearing, Kansas City, MO, 30 October 2001, on animal feeding regulation "Animal Proteins Prohibited in Ruminant Feed"-Code of Federal Regulations, Title 21, Part 589.2000.

Francis J, Ndlovu LR. 1995. Improving feeding management and work performance of mashona oxen through strategic supplementation with cobsheath-groundnut stover. Tropical Animal Health and Production 27: 249-257.

Gusha J, Halimani TE, Katsande S, Zvinorova PI. 2015a. The effect of Opuntia ficus indica and forage legumes based diets on goat productivity in smallholder sector in Zimbabwe. Small Ruminant Research 125: 21-25.

Gusha J, Katsande S, Zvinorova PI, Halimani TE, Chiuta T. 2015b. Performance of growing cattle on poor-quality rangelands supplemented with farm-formulated protein supplements in Zimbabwe. Journal of Animal Physiology and Animal Nutrition 99: 905-912.

Gwanzura T, Ngambi JW, Norris D. 2011. Effects of selected legume species and forage sorghum hay grown in Limpopo province on voluntary intake and relative palatability indices of Pedi goats. Asian Journal of Animal and Veterinary Advances 6: 1249-1255.

Holness DH (ed.). 1998. Beef production manual (rev. edn). Harare: Cattle Producers' Association.

Jokthan GE, Muhammad SA, Osuhur CU. 2013. Effect of cottonseed cake replacement with broiler litter on performance of Yankasa rams fed maize husk basal diets. FUTA Journal of Research in Sciences 1: 147-155.

Madzimure J, Musimurimwa C, Chivandi E, Gwiriri L, Mamhare E. 2011. Milk yield and quality in Guernsey cows fed cottonseed cake-based diets partially substituted with baobab (Adansonia digitata L.) seed cake. Tropical Animal Health Production 43: 77-82.

Mapiye C, Foti R, Chikumba N, Poshiwa X, Mwale M, Chivuraise C, Mupangwa JF. 2006. Constraints to adoption of forage and browse legumes by smallholder dairy farmers in Zimbabwe. Livestock Research for Rural Development 18: Art. \#175.

Matenga VR, Ngongoni NT, Titterton M, Maasdorp BV. 2003 Mucuna seed as a feed ingredient for small ruminants and effect of ensiling on its nutritive value. Tropical and Subtropical Agroecosystems 1: 97-105.

Matibvu T, Maburutse BE, Mbiriri DT, Kashangura MT. 2012. Constraints and opportunities for increased livestock production in communal areas: a case study of Simbe, Zimbabwe. Livestock Research for Rural Development 24: Art. \#165.

Mhaka V. 2014. The effects of substituting cotton seedcake with dried poultry litter in the pen fattening of beef cattle. BSc thesis, Midlands State University, Zimbabwe.

Milford R, Minson DJ. 1966. Intake of tropical pasture species. Proceedings of the International Grassland Congress 9: 815-822.

Mlote SN, Mdoe NSY, Isinika AC, Mtenga LA. 2013. Profitability analysis of small scale beef cattle fattening in the Lake Zone in Tanzania. Journal of Agricultural Economics and Development 2: 203-216.

MoAMID (Ministry of Agriculture, Mechanisation and Irrigation Development). 2014. Second round crop and livestock assessment report. Harare: MoAMID.

Muinga RW, Saha HM, Mureithi JG. 2003. The effect of mucuna (Mucuna prupriens) forage on the performance of lactating cows. Tropical and Subtropical Agroecosystems 1: 87-91.

Murphy AM, Colucci PE. 1999. A tropical forage solution to poor quality ruminant diets: a review of Lablab purpureus. Livestock Research for Rural Development 11(2).

Murungweni C, Mabuku O, Manyawu GJ. 2004. Mucuna, lablab and paprika calyx as substitutes for commercial protein sources used in dairy and pen-fattening diets by smallholder farmers of Zimbabwe. In: Whitbread A, Pengelly BC (eds), Tropical legumes for sustainable farming systems in southern Africa and Australia. ACIAR Proceedings no. 115. Canberra: Australian Centre for International Research. pp 28-37.

Packard CE, Muir JP, Wittie RD. 2007. Effects of groundnut stover or Bermudagrass hay supplementation to doe kids on winter hardwood range. Small Ruminant Research 67: 1-6.

Prasad VL, Khombe CT, Nyathi P. 1994. Feeding crop residues for improved draft power. In: Starkey P, Mwenya E, Stares J (eds), Improving animal traction technology. Wageningen: Technical Centre for Agricultural and Rural Cooperation. pp 164-166.

SAS Institute. 2012. SAS/STAT 12.1 user's guide. Cary: SAS Institute.

Israel SH, Pearson RA. 2000. Strategies to improve the effectiveness of supplementary feeding of working cattle in semi-arid crop/livestock systems. In: Kaumbutho PG, Pearson RA, Simalenga TE (eds), Empowering farmers with animal traction: proceedings of the workshop of the Animal Traction Network for Eastern and Southern Africa (ATNESA), 20-24 September 1999, Mpumalanga, South Africa. Cape Town: ATNESA. pp 146-152.

Tadele Y, Amha N. 2015. Use of different non protein nitrogen sources in ruminant nutrition: a review. Advances in Life Science and Technology 29: 100-105.

Tavirimirwa B, Manzungu E, Ncube S. 2012. The evaluation of dry season nutritive value of dominant and improved grasses in fallows in Chivi district, Zimbabwe. Online Journal of Animal Feed Research 2: 470-474.

Topps JH, Oliver J (eds). 1993. Animal foods of Central Africa. Zimbabwe Agricultural Journal Technical Handbook no. 2. Harare: Modern Farming Publications.

SAS Institute. 2012. User's guide: statistics. Cary: SAS Institute.

Wanapat M. 2000. Rumen manipulation to increase the efficient use of local feed resources and productivity of ruminants in the tropics. Asian-Australian Journal of Animal Science 13(Suppl. July 2000 B): $59-67$.

World Bank. 2008. Agriculture for development. World Development Report 2008. Washington, DC: The World Bank. 